\title{
(2) OPEN ACCESS \\ Transcolonic endoscopic appendectomy: a novel natural orifice transluminal endoscopic surgery (NOTES) technique for the sessile serrated lesions involving the appendiceal orifice
}

\author{
Tao Chen, Aiping Xu, Jingjing Lian, Yuan Chu, Haibin Zhang, Meidong Xu
}

- Additional material is published online only. To view, please visit the journal online (http://dx.doi.org/10.1136/ gutjnl-2020-323018).

Endoscopy Center, Shanghai East Hospital, Tongji University School of Medicine, Shanghai, China

\section{Correspondence to} Dr Meidong Xu, Endoscopy Center, Shanghai East Hospital, Tongji University School of Medicine, Shanghai, China; 1800512@tongji.edu.cn

Received 6 September 2020 Revised 3 January 2021 Accepted 8 January 2021
Check for updates

(c) Author(s) (or their employer(s)) 2021. Re-use permitted under CC BY-NC. No commercial re-use. See rights and permissions. Published by BMJ.

To cite: Chen T, Xu A, Lian J, et al. Gut Epub ahead of print: [please include Day Month Year]. doi:10.1136/ gutin|-2020-323018

\section{MESSAGES}

With the advancement in endoscopic technology, the discovery of novel endoscopic techniques such as endoscopic full-thickness resection (EFTR) provides new contents for natural orifice transluminal endoscopic surgery (NOTES) and endoscopic therapeutic options for patients with gastrointestinal lesions. Here, we present transcolonic endoscopic appendectomy as an expansion of full thickness resection with extraluminal dissection of the appendix for minimally invasive treatment of the sessile serrated lesions (SSLs) deeply involving the appendiceal orifice; final closure is done by endoloop and clip placement. The procedure was successful in four patients with good follow-up results at the 3 months colonoscopic control. Generally, transcolonic endoscopic appendectomy extends endoscopic resection technique and will promisingly replace combined endoscopic and laparoscopic surgery technique. This technique should be studied further.

\section{IN MORE DETAIL}

SSLs are colorectal lesions with malignant potential ${ }^{1}$ and should be removed as accurately as possible. ${ }^{2}$ In dilemma, more than half of the appendiceal adenomas are SSLs ${ }^{34}$ and therapeutic methods are controversial: endoscopic resection, extended laparoscopic appendectomy or combined laparoscopic appendectomy is traditionally optional. ${ }^{1}$ Surgical resection remains the standard and endoscopic resection is sometimes performed as an alternative to surgical intervention. However, conventional endoscopic resection of SSLs involving the appendiceal orifice has very critical limitations: endoscopic resection into the appendiceal orifice deeply itself carries a risk of appendicitis and it cannot guarantee a negative deep margin for lesions growing into the lumen of the appendix. ${ }^{2}$ To overcome these disadvantages, we present a novel NOTES technique, transcolonic endoscopic appendectomy, for the SSL involving the appendiceal orifice. This technique takes advantage of EFTR technique, which includes the endoscopic full-thickness incision and defect closure techniques. Here, we report a series of patients with the SSLs deeply involving the appendiceal orifice removed by transcolonic endoscopic appendectomy technique (figure 1). Patient demographics, procedure details, outcomes, histology and follow-up after transcolonic endoscopic appendectomy are shown in table 1 . No special patients' history and family history were found. Before the procedure, contrast-enhanced CT of the abdomen and three-dimensional reconstruction technique were employed to evaluate the condition of the appendix and understand its relationship with neighbour organs (figure 1A). After the procedure, the size of the specimen was calculated and examined (figure 1I). The pathological examination was also performed (figure $1 \mathrm{~K}$ ). All patients received intravenous antibiotics for 6 days postoperatively. Clear fluids were resumed at postoperative day 6 (average, table 1). All of the patients felt no discomfort and were discharged at postoperative day 8 (average, table 1). All patients were recommended a colonoscopy in 3 months after the procedure and the follow-up results were also shown in figure $1 \mathrm{~J}$ and table 1.

\section{DESCRIPTION OF TECHNOLOGY}

The patient was under general anaesthesia and endotracheal intubation. During the procedure, single and double channel endoscope (PCF-Q260JI and GIF-2TQ260M, Olympus, Japan) were used. The high-frequency generator (VIO200D, ERBE, Germany) was prepared for the procedure and a carbon dioxide $\left(\mathrm{CO}_{2}\right)$ insufflator (Olympus) was employed for $\mathrm{CO}_{2}$ gas insufflations. HOOK knife (KD620QR/UR, Olympus, Japan), IT knife (KD-611L, Olympus, Japan), hot biopsy forceps (HBF-23/2000, Micro-Tech Nanjing, China), injection needles (VIN-23, COOK, USA), snares (DPS-A-28/23, Micro-Tech Nanjing, China), metal clips (D26-195C, Micro-Tech Nanjing, China) and endoloop (MAJ-340, Olympus, Japan) were also prepared. A mixed solution of normal saline containing $0.4 \%$ indigo carmine and $0.025 \mathrm{mg} / \mathrm{mL}$ epinephrine was used for submucosal injection. Procedure steps were described as follows:

Step 1: intestinal cleaning: A transparent cap was attached to the tip of the endoscope. Terminal ileum, cecum and ascending colon were washed repeatedly to clean the operative region and to avoid the intestinal juice leaking into the abdomen.

Step 2: lesion evaluation: Before the procedure, the lesion was also evaluated again, by using white light, narrow band interference technique and indigo carmine dyeing.

Step 3: EFTR: After a mixture solution was injected into the submucosa, a circumferential 


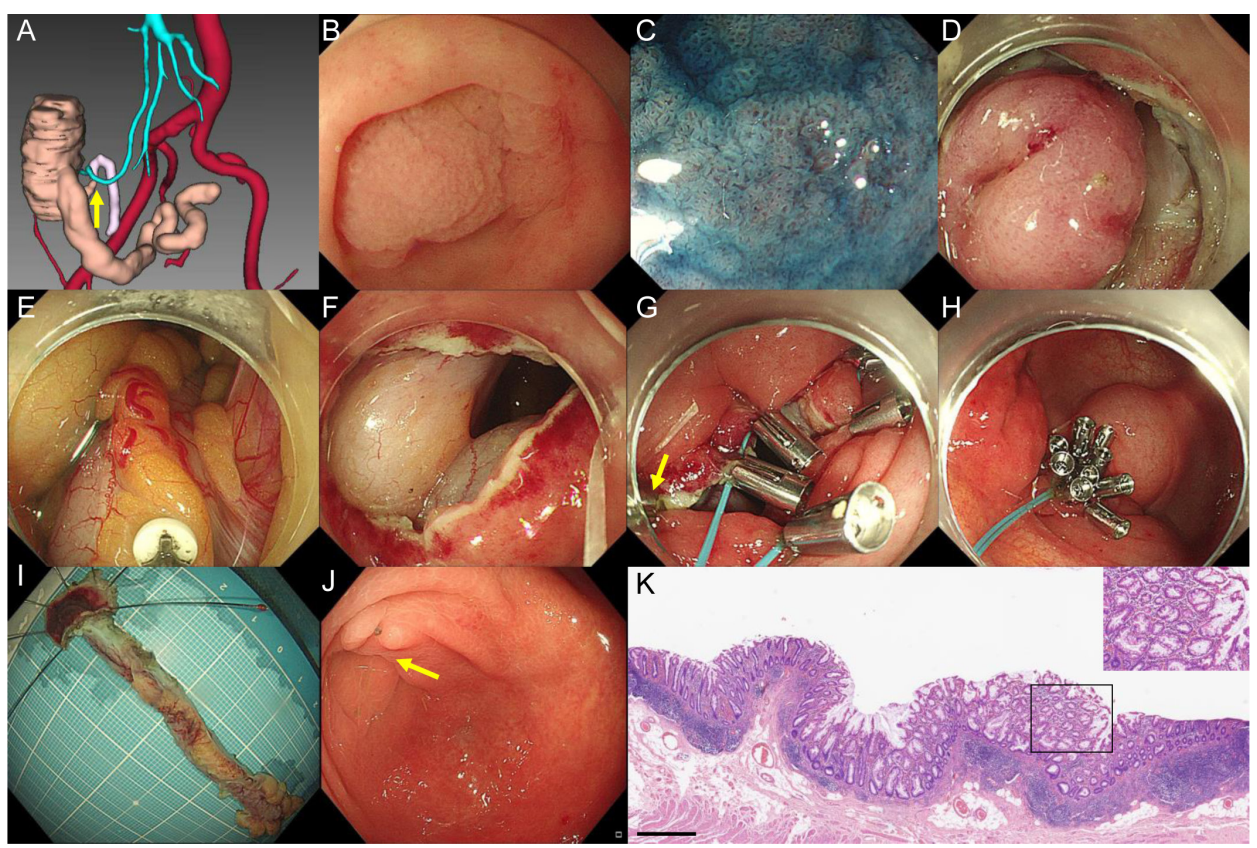

Figure 1 Transcolonic endoscopic appendectomy for the SSL involving the appendiceal orifice. (A) Three-dimensional reconstruction images showing the appendix (yellow arrow) and adjacent bowels and vessels. (B) An endoscopic white-light image showing the SSL involving the appendiceal orifice. (C) An image from chromoendoscopy following indigo carmine dye spraying clearly showing the SSL. (D) An intraprocedural view showing endoscopic full-thickness resection of the cecum tissue around the appendiceal orifice. (E) Endoscopic dissection of the mesoappendix along the appendix by an IT knife. (F) The cecal defection. (G) An intraprocedural endoscopic image showing clips and endoloop used for closing the cecal defect (yellow arrow: the dental-floss assistance). (H) The cecal defect was perfectly closed by clips and endoloop after transcolonic endoscopic appendectomy. (I) The specimen was calculated and examined. (J) An endoscopic follow-up image showing the cecum in 3 months after discharge (yellow arrow: the wound healing scar). (K) Pathological confirmation and diagnosis of the SSL (bar: $100 \mu \mathrm{m}$ ): increased gland diameter and enlarged opening; microbubble-like mucous cells; jagged crypts, widened and inverted crypt base.

submucosal incision was made by the endoscopic submucosal dissection technique and full-thickness resection around the lesion and appendiceal orifice was made by EFTR technique. Incision into the submucosa, the muscularis propria and serosal layer around the lesion was performed with a Hook knife.

Step 4: appendix dissection: In appendix dissection procedure, the IT knife was employed to dissect the mesoappendix along the appendix. During the dissection, the hot biopsy forceps was used to coagulate the mesentery vessels. During the procedure, a $20 \mathrm{~mL}$ syringe with $10 \mathrm{~mL}$ normal saline can be used to insert into the right lower quadrant to release the gas.

Step 5: appendix extraction: After the appendix was resected, a snare was used to take it out from the bowel lumen.

Step 6: defect closure: After careful hemostasis, the cecal defect was closed by the endoloop and metal clips by using a two-channel endoscope, which allowed simultaneous insertion of the endoloop and clip applicators. A clip with dental floss was used to turn the mucosa of the defect into the inside of the cecum for aligning the resection margin. The endoloop was tightened slightly and finally the defect was closed perfectly. During the procedure, the puncture syringe can be kept in place until the defect closure has been completed. After the defect closure has been completed, $\mathrm{CO}_{2}$ was injected to check closure effect.

\section{VIDEO DESCRIPTION}

Online supplemental video presents the transcolonic endoscopic appendectomy technique for the treatment of the SSLs involving the appendiceal orifice. The colonoscopy was performed before transcolonic endoscopic appendectomy and examined the SSL carefully. This SSL was successfully treated by transcolonic endoscopic appendectomy with no procedurerelated adverse events.

Table 1 Patient demographics, procedure details, outcomes, histology and follow-up

\begin{tabular}{|c|c|c|c|c|c|c|c|c|c|c|}
\hline No & Sex & $\begin{array}{l}\text { Age } \\
\text { (years) }\end{array}$ & $\begin{array}{l}\text { Lesion size } \\
(\mathrm{cm})\end{array}$ & $\begin{array}{l}\text { Procedure } \\
\text { time (minutes) }\end{array}$ & $\begin{array}{l}\text { Additional } \\
\text { surgery }\end{array}$ & $\begin{array}{l}\text { Adverse } \\
\text { events }\end{array}$ & $\begin{array}{l}\text { Fasting } \\
\text { time } \\
\text { (days)* }\end{array}$ & $\begin{array}{l}\text { Hospital } \\
\text { stay } \\
\text { (days)* }^{*}\end{array}$ & Histological findings & 3-month follow-up \\
\hline 1 & M & 36 & 1.5 & 115 & No & No & 7 & 10 & $\begin{array}{l}\text { Appendix and orifice SSL; margin: } \\
\text { pHMO, pVMO }\end{array}$ & Wound healed; no recurrence \\
\hline 2 & $\mathrm{M}$ & 66 & 1.5 & 106 & No & No & 4 & 7 & $\begin{array}{l}\text { Appendix and orifice SSL; margin: } \\
\text { pHMO, pVMO }\end{array}$ & Wound healed; no recurrence \\
\hline 3 & $\mathrm{~F}$ & 71 & 1.8 & 110 & No & No & 4 & 7 & $\begin{array}{l}\text { Appendix and orifice SSL; margin: } \\
\text { pHM0, pVMO }\end{array}$ & Wound healed; no recurrence \\
\hline 4 & $\mathrm{~F}$ & 63 & 2.0 & 120 & No & No & 5 & 8 & $\begin{array}{l}\text { Appendix and orifice SSL; margin: } \\
\text { pHMO, pVMO }\end{array}$ & Wound healed; no recurrence \\
\hline
\end{tabular}

*Fasting time and hospital stay indicate days after procedure.

F, female; M, male; SSL, sessile serrated lesion. 


\section{COMMENTS}

The treatment of the SSLs involving the appendiceal orifice is controversial. Surgical resection or laparoscopic appendectomy is thought to be the standard therapeutic method before. With the development of endoscopy techniques, endoscopic resection could be used in most colorectal adenomatous lesions. However, common endoscopic resection techniques for the treatment of SSLs growing into the lumen of the appendix are incompetent. Transcolonic endoscopic appendectomy is a novel NOTES technique initiated by EFTR and provides an alternative for the SSLs deeply involving the appendiceal orifice. Another potential advantage of transcolonic endoscopic appendectomy is that the resection range is more accurate. This is important because we have no need of laparoscopic appendectomy with full cecal mobilisation to afford amaximal cecal cuff.

The ceceal defect closure after endoscopic appendectomy is an important part of this novel technique. In this study, the defect in the wall was closed by an endoloop through a double-channel endoscope. The loop was opened around the defect and endoclips (inserted through the other channel) were applied over the loop at several locations. The loop was then closed to approximate the edges of the defect. This closure technique is effective and has been widely accepted in clinical practice of EFTR techniques. ${ }^{5-7}$ During the procedure, a $20 \mathrm{~mL}$ syringe with $10 \mathrm{~mL}$ normal saline can be used to insert into the right lower quadrant to release the gas $\left(\mathrm{CO}_{2}\right)$. This puncture syringe can be kept in place until the defect closure has been completed. After the defect closure has been completed, $\mathrm{CO}_{2}$ was injected to check closure effect. Notably, better closure techniques should be developed to simplify the procedure and ensure the success of this novel NOTES technique in the future.

As a consequence, this novel NOTES technique has a clear potential for clinical use. We believe that transcolonic endoscopic appendectomy provides a precise and safe way to treat the SSLs involving the appendiceal orifice. Furthermore, the endoloop-clip technique provides a safe way to close the cecal defect. Future studies with a larger number of patients are necessary to confirm the outcomes of the transcolonic endoscopic appendectomy technique and develop better closure techniques.
Contributors Study concept and design: MX; acquisition of data: $\mathrm{TC}, \mathrm{AX}$ and $\mathrm{HZ}$; analysis and interpretation of data: MX and TC; drafting of the manuscript: TC; critical revision of the manuscript for important intellectual content: $\mathrm{TC}$, JL and $\mathrm{YC}$; obtained funding: MX and TC; technical or material support: MX; study supervision: $\mathrm{MX}$.

Funding This study was supported by grants from The Top-level Clinical Discipline Project of Shanghai Pudong (PWYgf2018-0), National Natural Science Foundation of China (82073224, 82072684 and 81872351) and Shanghai Committee of Science and Technology (18140900100).

Competing interests None declared.

Patient and public involvement Patients and/or the public were not involved in the design, or conduct, or reporting, or dissemination plans of this research.

Patient consent for publication Not required.

Provenance and peer review Not commissioned; internally peer reviewed.

Open access This is an open access article distributed in accordance with the Creative Commons Attribution Non Commercial (CC BY-NC 4.0) license, which permits others to distribute, remix, adapt, build upon this work non-commercially, and license their derivative works on different terms, provided the original work is properly cited, appropriate credit is given, any changes made indicated, and the use is non-commercial. See: http://creativecommons.org/licenses/by-nc/4.0/.

\section{ORCID iD}

Meidong Xu http://orcid.org/0000-0002-7219-5826

\section{REFERENCES}

1 Rex DK, Ahnen DJ, Baron JA, et al. Serrated lesions of the colorectum: review and recommendations from an expert panel. Am J Gastroenterol 2012;107:1315-29.

2 Huang ES, Chumfong IT, Alkoraishi AS, et al. Combined endoscopic mucosal resection and extended laparoscopic appendectomy for the treatment of periappendiceal, cecal, and appendiceal adenomas. J Surg Res 2020;252:89-95.

3 Murakami T, Sakamoto N, Nagahara A. Clinicopathological features, diagnosis, and treatment of sessile serrated adenoma/polyp with dysplasia/carcinoma. J Gastroenterol Hepatol 2019;34:1685-95.

4 Kahi CJ, Li X, Eckert GJ, et al. High colonoscopic prevalence of proximal colon serrated polyps in average-risk men and women. Gastrointest Endosc 2012;75:515-20.

5 ASGE Technology Committee, Aslanian HR, Sethi A, et al. ASGE guideline for endoscopic full-thickness resection and submucosal tunnel endoscopic resection. VideoGIE 2019;4:343-50.

6 Rajan E, Wong Kee Song LM. Endoscopic full thickness resection. Gastroenterology 2018; 154:1925-37.

7 Chen H, Li B, Li L, et al. Current status of endoscopic resection of gastric subepithelial tumors. Am J Gastroenterol 2019;114:718-25. 